\title{
Diversity, Abundance, Richness, and Birds of Conservation Interest in Nyando Sugar Belt, Muhoroni Sub-County, Lake Victoria Basin, Western Kenya
}

\author{
Daniel Mokaya Mogaka, Shadrack Muya, Francis Ndwigah, Paul Ndang'ang'a \\ Jomo Kenyatta University of Agriculture and Technology (Jkuat), Nairobi, Kenya \\ Email: damomo2013@gmail.com,smuya@jkuat.ac.ke, irerifin@gmail.com,dean.sbs@jkuat.ac.ke, Kariuki.ndanganga@gmail.com
}

How to cite this paper: Mogaka, D.M., Muya, S., Ndwigah, F. and Ndang'ang'a, P. (2019) Diversity, Abundance, Richness, and Birds of Conservation Interest in Nyando Sugar Belt, Muhoroni Sub-County, Lake Victoria Basin, Western Kenya. Open Journal of Animal Sciences, 9, 268-285. https://doi.org/10.4236/ojas.2019.93023

Received: April 19, 2019

Accepted: May 11, 2019

Published: May 14, 2019

Copyright $\odot 2019$ by author(s) and Scientific Research Publishing Inc. This work is licensed under the Creative Commons Attribution International License (CC BY 4.0).

http://creativecommons.org/licenses/by/4.0/

c) (i) Open Access

\begin{abstract}
Thus far, no expedition has comprehensively surveyed the composition of bird species in the dilapidated habitats of Nyando sugar belt, Western Kenya. This has made it difficult unearthing equilibrium between agricultural growth and bird species conservation. In response, we conducted bird assessment by stratifying the expedition area into farmlands and shrub-land. We then sampled birds by the standard point count method and opportunistic counts within a $30 \mathrm{~m}$ radius parcel of land. We exhaustively observed 1450 birds of 122 species. The farmland recorded a density of $2.065 \pm 1.11$ birds per hectare whereas the shrub-land had a density of $1.644 \pm 0.70$ birds per hectare. Nyando sugar belt was a diverse community with a Shannon diversity index value ( $\left.H^{\prime}\right)$ of 3.225 regardless of the birds being constrained in certain habitats. The magnitude of the disparity in true diversity indicated that the farmland was 4 times more diverse than the shrub-land. The facts promoted by this research validate the incorporation of bird conservation in the farmland and formulation of avian conservation strategies.
\end{abstract}

\section{Keywords}

Diversity, Abundance, Richness, Birds, Nyando, Conservation, Migration, Forest Dependency, Kenya

\section{Introduction}

In Nyando sugar belt, more land is being converted from natural habitats into sugarcane plantations and human habitats. The remnant indigenous vegetation is unsustainably being overexploited for charcoal, firewood and construction 
materials. Despite efforts to improve the management and conservation of this landscape, the problem of natural resource dilapidation and consequential loss of biodiversity continue to persist. Consistent with Serkecioglu (2004) birds are imperative in indicating alteration in the health status of the environment [1]. As per Gregory (2003) they make superb indicators for biodiversity, the environment and the sustainability of human activities [2]. This stresses the need to study their composition after every five years. Worldwide and particularly in Kenya, many studies on different aspects of birds have been undertaken. So far and despite all these efforts, no study has been carried out in Nyando sugar belt on the composition of birds, a gap that this expedition sought to fill.

According to IUCN, 2008, habitat loss is the main threat facing $85 \%$ of all the bird species documented in the IUCN Red List. Though human activities have allowed the expansion of a few species, they have caused population decreases or extinction in many other species. Globally, many bird species are declining, with 1227 species listed as threatened by BirdLife International and the IUCN (2009). As stated by Steadman (2006), an excess of 100 species of birds have become extinct in historical times, although the most dramatic human instigated extinctions ensued in the Pacific Ocean as humans populated the islands of Melanesia, Polynesia, and Micronesia during which, an estimated 750 - 1800 species of birds became extinct [3].

Birds reside in a wide range of ecological positions. Some are generalists, while others are highly specialized in their habitat or requirements for foraging. Even within a lone habitat, the niches occupied by various species vary, with some feeding in the forest canopy, others beneath the canopy, and still others on the floor of the forest. Forest birds may be insectivores, frugivorous, and nectarivores. According to Sekercioglu et al. (2006), birds of prey specialize in hunting mammals or other birds, while vultures are specialized scavengers [4].

The main objective of this survey was to provide results on different ornithological aspects of birds in Nyando sugar belt. We hypothesized that the diversity, abundance, and richness of birds were insignificant between the study sites. Specifically, we established the diversity, abundance, richness, migration status, and forest dependency and conservation status of birds. The knowledge obtained from this research will advantage the government of Kenya, non-governmental organizations, the local community and conservationists in reaching sound decisions on subjects relating to conservation of birds in Nyando sugar belt.

\section{Materials and Methods}

\subsection{Study Area}

This expedition was conducted in Nyando sugar belt, Latitude of $0^{\circ}$ and $26^{\prime}$ south and Longitude of $34^{\circ} 52^{\prime}$ east and $35^{\circ} 19^{\prime}$ east [5]. This region has two major bird habitats i.e. farmlands and shrubland. The highest levels of rainfall occur between March to June and October to mid-December whereas low levels occur in late December, January, and February. The main threat facing birds of this 
area is the unsustainable exploitation of natural resources, particularly indigenous vegetation for charcoal, firewood and construction materials. Surprisingly no indigenous forest is left in Nyando sugar belt.

\subsection{Data Collection Methods}

For this bird survey, we preferred the standard point count method and opportunistic counts as the most applicable survey methods since they have proved effective for most researchers all over the world. Bibby et al. (1998) suggest fifty point count stations in each study area. In Nyando sugar belt, we randomly picked a total of five two kilometers long of line transects since they would collectively accommodate fifty $30 \mathrm{~m}$ radius point count plots, set at standard intervals of $200 \mathrm{~m}$. We used GPS (Global Positioning System) to set and spot the sampling stations. The observers stood at the center of the point count plots and recorded all birds seen or heard for a period of 10 minutes. Bird observations were conducted at 6.30 a.m. to 10.30 a.m. and 3.30 p.m. to 6.30 p.m. on good weather days. The birds were then identified with Zimmerman bird identification key [6]. We consistently organized random walks to exhaustively search for new bird sightings.

\section{Results}

\subsection{Bird Species Abundance}

A total of 1450 individual birds belonging to 122 species from 46 families were documented. In the shrubland the Little Swift (Apus affinis), Common Bulbul (Pycnonotus barbatus) and Tropical Boubou (Laniarius aethopicus) were the most abundant bird species (Figure 1) whilst in the farmland, the Bronze Mannikin

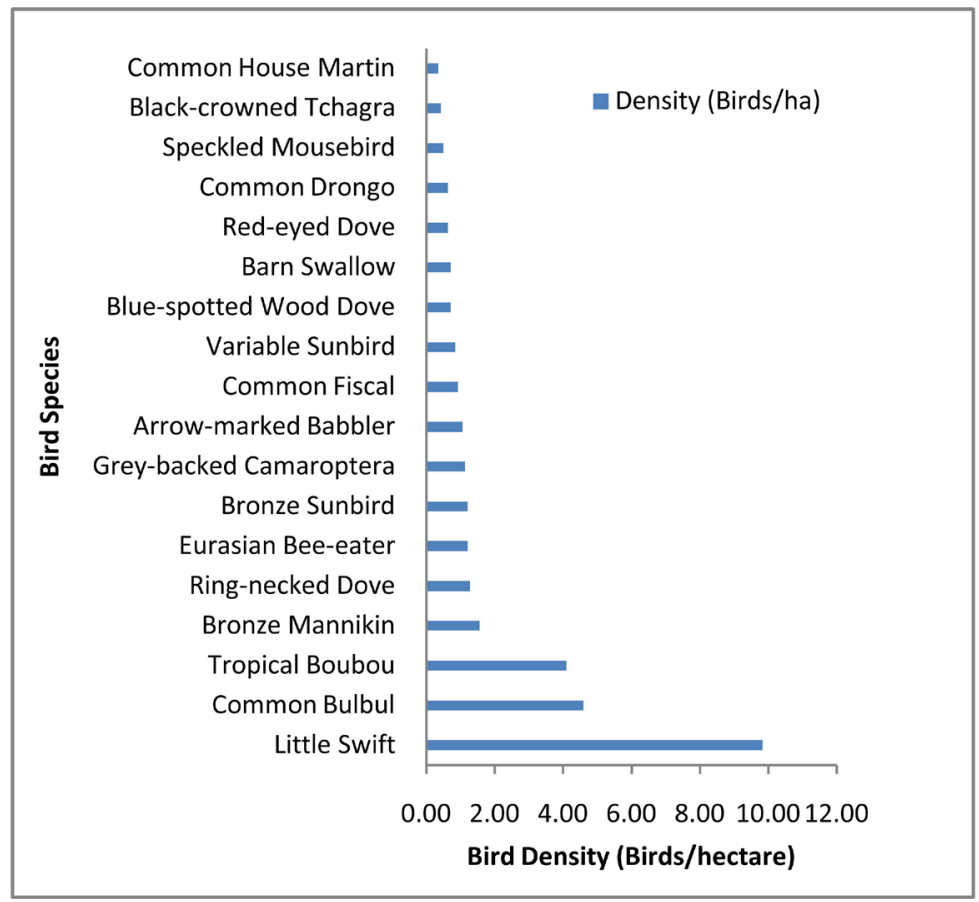

Figure 1. Shrubland bird density. 
(Spermestes cucculatus), the Little Swift (Apus affinis), the Common Bulbul (Pycnonotus barbatus) and the Fan-tailed Widowbird (Euplectes axillaris) were the most abundant bird species respectively (Figure 2).

Bird species abundance in the farmland had a mean of $2.065 \pm 1.11$ birds per hectare whereas the shrubland had a mean of $1.644 \pm 0.70$ birds per hectare.

\subsection{Bird Species Diversity}

Species diversity index was determined by use of Shannon Weiner diversity index $\left(H^{\prime}\right)$. This was purposed to show the number of different categories of bird species in a data set. It also accounted for how the individual bird species were distributed among the other bird species. The statistic that birds species diversity index $\left(H^{\prime}\right)$ value was 3.225 suggests that the study area was a diverse habitation in spite of birds being limited to specific habitats. The true diversity (Table 1) indicated that the magnitude of the difference in true diversity (effective number of species) revealed that the farmland was four times more diverse than the shrubland (Figure 3). We provided a checklist of all the bird species in Nyando sugar belt (Appendix 1).

\subsection{Bird Species Richness}

The farmlands had 86 species as contrasted to the indigenous shrub with 60 bird species (Table 2 and Figure 4). Shannon equitability index indicated that the

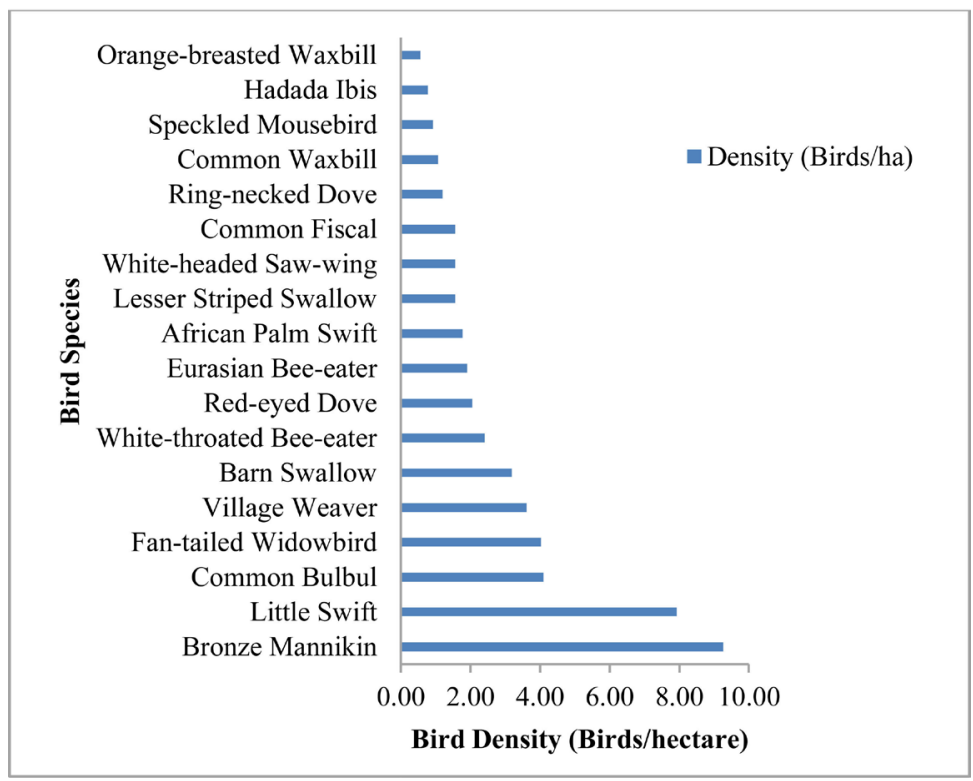

Figure 2. Agricultural farmlands bird density (Birds/hectare).

Table 1. Effective number of species (True diversity).

\begin{tabular}{ccc}
\hline Habitat & Shannon diversity index & Effective number of species \\
\hline Farmland & 3.90 & 49 \\
Shrubland & 2.55 & 13 \\
\hline
\end{tabular}




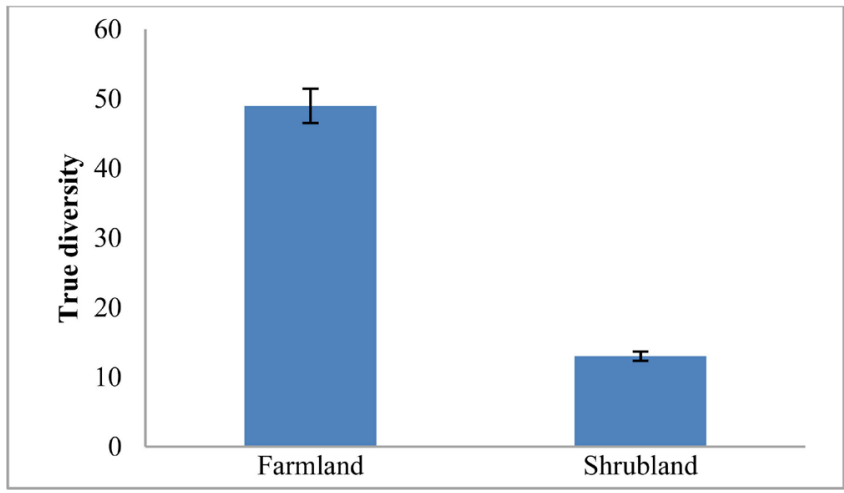

Figure 3. True diversity.

Table 2. Bird species richness per habitat.

\begin{tabular}{ccc}
\hline Habitat & Species Richness $(\mathrm{S})$ & Shannon Equitability $\left(\mathrm{E}_{\mathrm{H}}\right)$ \\
\hline Shrubland & 60 & 0.6081 \\
Farmland & 86 & 0.8891 \\
\hline
\end{tabular}

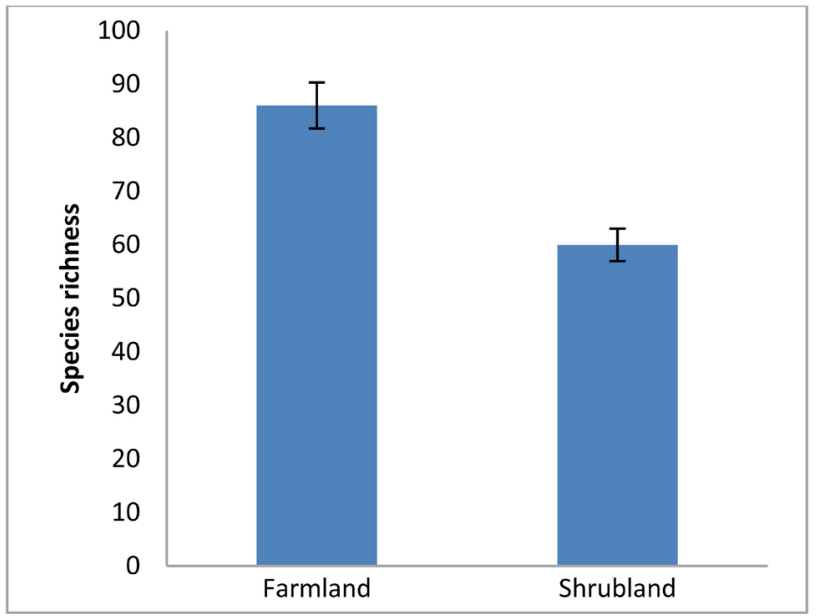

Figure 4. Bird species richness.

individual bird species were more evenly distributed in the farmlands than in the shrubland.

Species predictive curve modeled revealed that a complete bird community may not have been captured during the study. However, with more effort, species expected in Nyando sugar belt are at least 180 species (Figure 5). In the farmlands 86 bird species were cumulatively recorded while 60 bird species were observed in the shrubland (Figure 6).

\subsection{IUCN Red Listed Species in Nyando Sugar Belt}

A total of three species considered to be red-listed by IUCN were recorded: The Grey Crowned Crane (Balearica regulorum), endangered; the Fischer's Lovebird (Agapornis fischeri) near threatened; and the Steppe Eagle (Aquila nepalensis), endangered (Table 3). 


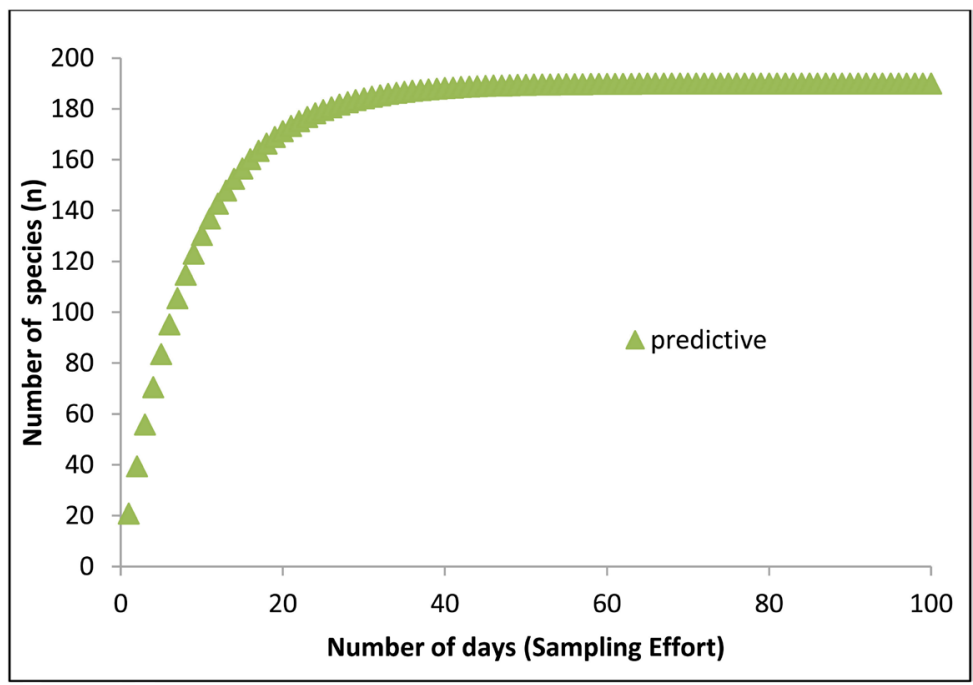

Figure 5. Species accumulation and predictive curves.

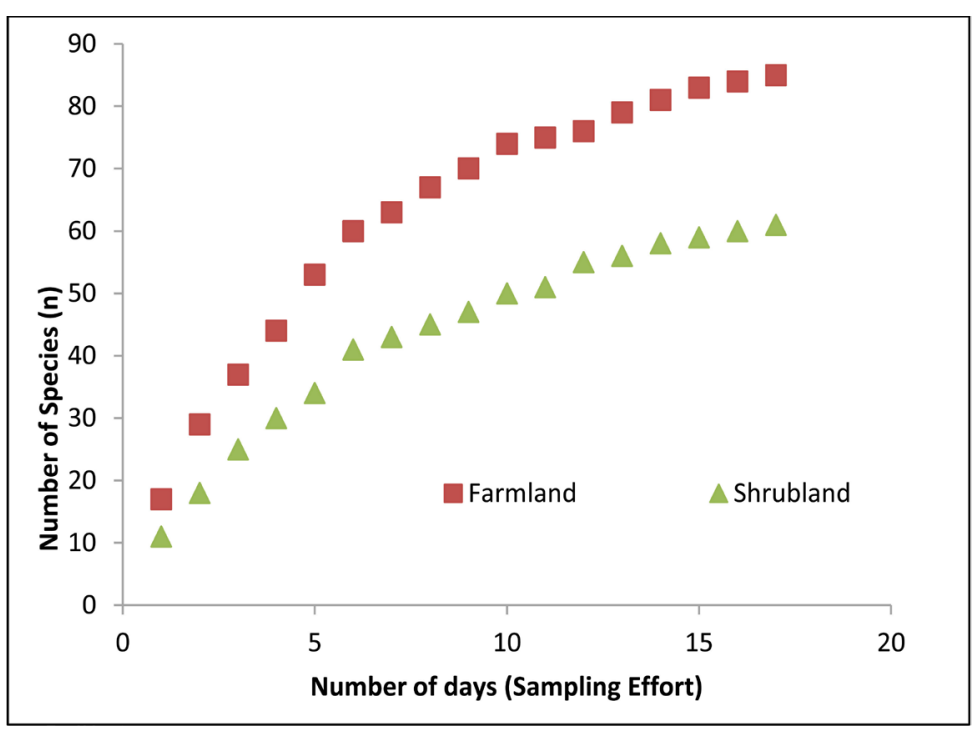

Figure 6. Species accumulation curves for the two habitats.

Table 3. Species listed in the IUCN red list.

\begin{tabular}{cccc}
\hline Common Name & Species Name & IUCN Status & Threat Score \\
\hline Grey Crowned Crane & Balearica regulorum & Endangered & 2 \\
Fischer's Lovebird & Agapornis fischeri & Near Threatened & 5 \\
Steppe Eagle & Aquila nepalensis & Endangered & 2 \\
& & Total score & 9 \\
\hline
\end{tabular}

\subsection{Forest Dependency in Nyando Sugar Belt}

Out of the 122 species of birds documented in Nyando sugar belt, there was no forest specialist (0\%). Six birds (5\%) were forest generalists (F), 40 birds (33\%) forest visitors (f) while 76 birds (62\%) were non-forest birds (Figure 7) and (Appendix 2). 
The farmlands had the highest numbers of forest visitors (22), forest generalists (4) and non-forest birds (59) contrariwise; the shrubland had the lowest numbers of forest visitors (20), forest generalists (2) and non-forest birds (39) respectively. Both habitats recorded zero forest specialists (Figure 8).

\subsection{Bird Migrants in Nyando Sugar Belt}

Twenty-one (21) of the 122 species of birds observed in the study area were biome-characteristic species. In the entire landscape, there were 6 Afrotropical migrants (am) comprising of 5\%, 12 Palearctic migrants (pm) comprising of $10 \%$ and 3 both Afrotropical and Palearctic migrants (am, pm) comprising of $2 \%$. The rest of the birds (101) were residents comprising 83\% (Figure 9).

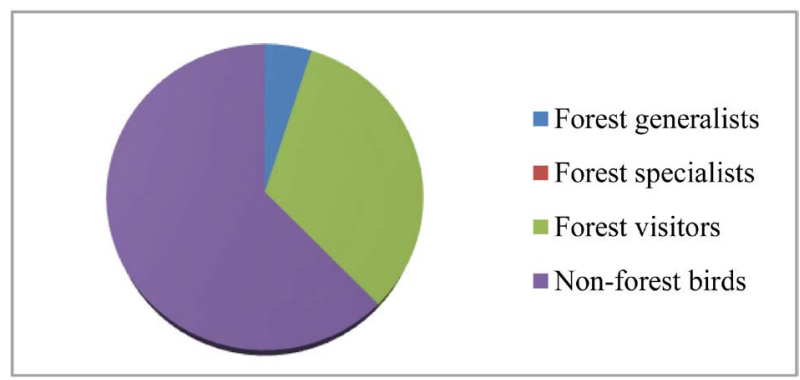

Figure 7. Forest dependency in Nyando sugar belt.

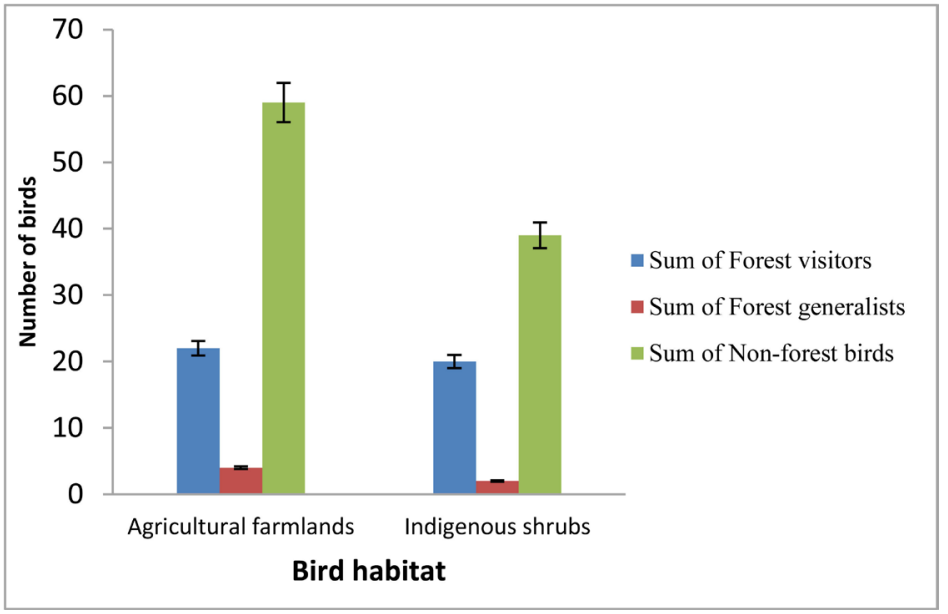

Figure 8. Forest dependency in the two habitats.

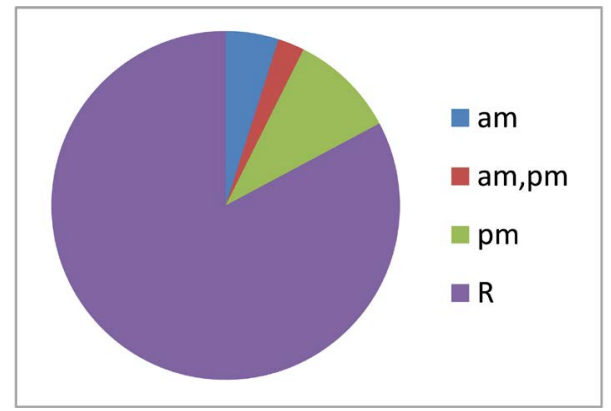

Figure 9. Migration status of birds in Nyando sugar belt. 


\section{Discussions}

\subsection{Bird Composition}

Bird abundance expressed in birds per hectare was different between the two habitats and largely high in areas with extensive human agricultural activities and low towards degraded natural habitats. This result agrees with the findings of Chace and Walsh (2006) and [7] who resolved that human-disturbed habitats offer heterogeneous conditions that draw human tolerant species [8]. The higher bird abundance in the farmlands could be attributed to a small number of avian species that can cohabit with human beings such as the Bronze Mannikin (Spermestes cucullatus), Common Bulbul (Pycnonotus barbatus), House Sparrow (Passer domesticus) and the Grey-headed Sparrow (Passer griseus) [8]. According to Gloria, 2002 [8], Pennington and Brail (2011) correspondingly found comparable results and deduced that higher bird abundance in the farmlands with settlement was prompted by landscape heterogeneity [9].

The low abundance in the shrubland is in agreement with Doggart (2005), who ascribes this to habitat degradation through human invasive activities like cattle grazing, fuel wood collection, pasture burning and charcoal processing [10]. Gloria, 2002 attributes this observation to the decline in vegetation cover for concealing from predators, shelter, food resources and breeding materials leading to competitive exclusion [8]. Rodriguez attributes this lower abundance in the shrubs to the migrations of bird species in response to particular species requirement such as nesting materials and procreation sites [11].

The highest species diversity in the farmland indicates a complex community in which a high degree of species interaction is possibly contrary to a higher dominance observed in the shrubland. This implies that few bird species pre-dominate the habitats. Though shrubs showed less bird diversity, higher dominance was due to persistence of native and generalist species [9].

Based on the point count method, bird species richness was high in the farmland. This was most likely the case attributable to diversity of vegetation types that supply essential bird resources for their survival. According to Scheiner (2003), species richness is high when bird species are drawn from diverse communities [12]. As stated by Laube (2003), the structure of bird community is most likely modeled by the composition and organization of its ecological niche [13]. The decrease in bird species richness due to human hindrance has been exhibited in bird habitats of the tropical regions [14], and indisputably in the natural shrubs of Nyando sugar belt. Human shrub destruction appears to lessen the vital resources needed by various avian species.

\subsection{Bird Species of Conservation Interest}

During the expedition, we recorded a number of species of birds of international conservation concern. Bennun and Njoroge (1996) noted that some bird species have intrinsic conservation interest for the reason that they are either endangered, threatened, vulnerable, rare, or endemic [15]. In Nyando sugar belt, the 
Fischer's Lovebird (Agapornis fischeri) was recorded as near threatened, Grey-crowned cranes (Balearica regulorum) as vulnerable, Steppe Eagle (Aquila nepalensis) as endangered and the Speckled Mousebird (Colius striatus) as endemic. This could be due to bird habitat loss which concurs with IUCN (2008) that habitat loss due to the growth of human activities such as urbanization, settlement and agricultural activities is the main threat facing $85 \%$ of all bird species described in the IUCN Red List.

Twenty-one (21) of the 122 species observed in Muhoroni Sub-County were biome-characteristic species. There were 12 Palearctic migrants (10\%), 6 Afrotropical migrants (5\%), 3 both Afrotropical and Palearctic migrants (2\%). The presence of these migratory birds in Nyando sugar belt could be attributed to this expedition coinciding with the time (October) migrant species are recorded in Kenya. These results go with the findings by Zimmerman et al. (1996) [6]

\subsection{Forest Dependency}

In Muhoroni Sub-County 6 birds (5\%) were forest generalists (F), 40 birds (33\%) forest visitors (f) while 76 birds (62\%) were non-forest birds. As the forest habitat becomes increasingly threatened, the birds they host are attracting enormous attention. According to Bennun (1996), studies on forest birds are worthwhile for at least two whys and wherefores [15]. First of all, the composition and richness of forest birds can signify its overall value for the conservation of biodiversity [16]. Secondly, habitat modification and its impacts and more hardly restoration can be gauged by censoring bird communities [17].

Conservationists need supplementary guidelines as to the worth of particular species of birds in pointing out forest condition. The $0 \%$ of 'forest specialists' (FF) is a signal that forests in Nyando have been altered to the magnitude that they cannot sustain forest specialists. As per Bennun and Njoroge (1999), forest generalists (F), occur in undisturbed forest and in forest edges, strips, gaps or in modified and fragmented forests [18]. However, forest generalists persistently continue to rely on forests for some resources [18]. The presence of these species in the Nyando sugar belt is attributed to the live fences composed of woody plants and scattered trees that provide breeding sites. Forest visitors (f species) comprised 33\% of all the birds observed. Bennun (1999) defines them as those birds which are often observed in the forest but are not fully dependent upon it [18]. They can certainly survive in habitats where the forest has completely become extinct [15]. The presence of these species in Muhoroni is an indication of forest deterioration.

\section{Conclusion}

There was clear variation in the diversity, abundance, and richness of bird species in the farmland and shrubland in Nyando sugar belt. This authenticates that dilapidation of bird habitations is steering birds to areas inhabited by humans. This relocation could be due to a potential deterioration of avian resources in the 
natural shrubs and an upwelling of these resources in the agricultural farms. Any pursuit that changes the original structure of habitat diversity influences the composition of the habitat. In a nutshell, anthropogenic activities that restore the complexity of the habitat incline to draw more bird species as juxtaposed to deteriorated indigenous habitats, and for that reason, surveys concerning the management of avian species within the farmland need to be spotlighted and allotted additional resources. To aid in the conservation of bird species in Nyando sugar belt, further research is necessary to keep an eye on the birds of conservation concern especially the IUCN red-listed species.

\section{Acknowledgements}

I would like to be appreciative to all the people who invigorated me in the course of writing this paper. I would also like to acknowledge our Sovereign God for conferring me vigor and optimism. Moreover, I wish to express my sincere thankfulness to Dr. Paul Ndang'ang'a, Dr. Shadrack Muya and Dr. Francis Ndwigah for their academic guidance.

\section{Conflicts of Interest}

The authors declare no conflicts of interest regarding the publication of this paper.

\section{References}

[1] Serkecioglu, C.H., Daily, G.C. and Ehirlich, P.R. (2004) Ecosystem Consequences of Bird Declines. Proceedings of the National Academy of Sciences of the United States of America, 101, 18042-18047. https://doi.org/10.1073/pnas.0408049101

[2] Gregory, R.D., Noble, D., Field, R., Marchant, J., Raven, M. and Gibbons, D.W. (2003) Using Birds as Indicators of Biodiversity. Ornis Hungarica, 12, 11-24.

[3] Steadman (2006) Extinction and Biogeography in Tropical Pacific Birds. University of Chicago Press, Chicago, 142-147.

[4] Sekercioglu (2006) Handbook of the Birds of the World: Old World Flycatchers to Old World Warblers. Barcelona. Lynx Edicions, 84-96.

[5] Raburu (2009) Macro-Invertebrate-Based Index of Biotic Integrity (M-IBI) for Monitoring the Nyando River, Lake Victoria Basin, Kenya. Scientific Research and Essay, 4, 1468-1477.

[6] Zimmerman (1996) Birds of Kenya and Northern Tanzania. Rushel Friedman Books, Halfway House.

[7] Sandstrom, U.G., Angelstam, P. and Mikusinski (2005) Ecological Diversity of Birds in Relation to the Structure of Urban Green Space. Landscape and Urban Planning, 77, 39-53. https://doi.org/10.1016/j.landurbplan.2005.01.004

[8] Bideberi, G. and Hassan, S. (2002) Diversity, Distribution and Abundance of Avifauna in Respect to Habitat Types SUA IR.

[9] Pennington, C. and Blair, R.B. (2011) Habitat Selection of Breeding Riperian Birds in an Urban Environment: Untangling the Relative Importance of Biophysical Element and Spatial Scale. Diversity and Distribution, 17, 506-518. 
https://doi.org/10.1111/j.1472-4642.2011.00750.x

[10] Doggart, N., et al. (2005) Biodiversity Surveys in the Forest Reserves of the Uluguru Mountains. Technical Paper for the Wildlife Conservation Society of Tanzania and Tanzanian Forest Conservation Group, DSM, Tanzania, 8-10.

[11] Rodriguez-Estrella, R. (2007) Land Use Changes Affect Distribution Pattern of Desert Birds in the Baja California Peninsula, Mexico. Diversity and Distribution, 13, 877-889. https://doi.org/10.1111/j.1472-4642.2007.00387.x

[12] Scheiner, S.M. (2003) Six Types of Species Area Curves. Global Ecology and Biogeography, 12, 441-447. https://doi.org/10.1046/j.1466-822X.2003.00061.x

[13] Laube, I., Breitbach, N. and Bohning, G.K. (2008) Avian Diversity in a Kenyan Agroecosytem: Effects of Habitat Structure and Proximity to the Forest. Journal of Ornithology, 149, 181-191. https://doi.org/10.1007/s10336-007-0258-6

[14] Cordeiro, N.J. (2005) Does Forest Fragmentation Impact Mixed Species Foraging Bird Flocks in Tanzania Forest. Proceedings of the 5th Annual Scientific Conference, Arusha, Tawiri, Tanzania, 157-165.

[15] Bennun, L.A. and Njoroge, P.K. (1996) Birds to Watch in East Africa: A Preliminary Red DTA List. Research Report of the Centre for Biodiversity. National Museums of Kenya, Nairobi, Ornithology 23.

[16] Thirgood and Heath (1994) Global Patterns of Endemism and the Conservation of Biodiversity. Systematics Association Special Volume 50.

[17] Furness, R.W. and Greenwood, J.J.D. (1993) Birds as Monitors of Environmental Change. Chapman and Hall, London. https://doi.org/10.1007/978-94-015-1322-7

[18] Bennun, L.A. and Njoroge (1999) Important Bird Areas in Kenya. Nature Kenya, Nairobi. https://doi.org/10.5962/bhl.title.87589 


\section{Additional Materials}

\section{Appendix 1. Nyando Sugar Belt Checklist of Bird Species Observed}

\begin{tabular}{|c|c|c|c|c|}
\hline Family & Common Name & Scientific Name & Migration & $\begin{array}{l}\text { IUCN Red } \\
\text { List Status }\end{array}$ \\
\hline Accipitridae & African Black-shouldered Kite & Elanus caeruleus & $\mathrm{R}$ & $\mathrm{LC}$ \\
\hline Accipitridae & Black Kite & Milvus migrans & $\mathrm{am}, \mathrm{pm}$ & $\mathrm{LC}$ \\
\hline Accipitridae & Common Buzzard & Buteo buteo & $\mathrm{PM}$ & $\mathrm{LC}$ \\
\hline Accipitridae & Palm-nut Vulture & Gypohierax angolensis & $\mathrm{R}$ & $\mathrm{LC}$ \\
\hline Accipitridae & Steppe Eagle & Aquila nepalensis & $\mathrm{PM}$ & $\mathrm{EN}$ \\
\hline Accipitridae & Wahlberg's Eagle & Aquila wahlbergi & $\mathrm{am}$ & LC \\
\hline Accipitridae & Western Banded Snake Eagle & Circaetus cinerascens & $\mathrm{R}$ & LC \\
\hline Accipitridae & Western Marsh Harrier & Circus aeruginosus & $\mathrm{PM}$ & $\mathrm{LC}$ \\
\hline Acciptridae & African Harrier Hawk & Polyboroides typus & $\mathrm{R}$ & $\mathrm{LC}$ \\
\hline Turdidae & African Thrush & Turdus pelios & $\mathrm{R}$ & LC \\
\hline Alaudidae & Fawn-coloured Lark & Mirafra africanoides & $\mathrm{R}$ & LC \\
\hline Alaudidae & Flappet Lark & Mirafra rufocinnamomea & $\mathrm{R}$ & $\mathrm{LC}$ \\
\hline Motacillidae & African Pied Wagtail & Motacilla aguimp & $\mathrm{R}$ & LC \\
\hline Alcedinidae & Malachite Kingfisher & Alcedo cristata & $\mathrm{R}$ & $\mathrm{LC}$ \\
\hline Alcedinidae & Woodland Kingfisher & Halcyon senegalensis & $\mathrm{R}$ & $\mathrm{LC}$ \\
\hline Anatidae & White-faced Whistling Duck & Dendrocygna viduata & $\mathrm{R}$ & LC \\
\hline Apodidae & African Palm Swift & Cypsiurus parvus & $\mathrm{R}$ & $\mathrm{LC}$ \\
\hline Ardeidae & Black-headed Heron & Ardea melanocephala & $\mathrm{R}$ & LC \\
\hline Ardeidae & Grey Heron & Ardea cinerea & am, pm & LC \\
\hline Ardeidae & Little Egret & Egretta garzetta & $\mathrm{R}$ & $\mathrm{LC}$ \\
\hline Ardeidae & Striated Heron & Butorides striata & $\mathrm{R}$ & $\mathrm{LC}$ \\
\hline Campephagidae & Black Cuckooshrike & Campephaga flava & am & $\mathrm{LC}$ \\
\hline Estrildidae & Bronze Mannikin & Spermestes cucculatus & $\mathrm{R}$ & LC \\
\hline Ardeidae & Cattle Egret & Bubulcus ibis & $\mathrm{am}$ & $\mathrm{LC}$ \\
\hline Capitonidae & Double-toothed Barbet & Lybius bidentatus & $\mathrm{R}$ & $\mathrm{LC}$ \\
\hline Capitonidae & Spot-flanked Barbet & Tricholaema lacrymosa & $\mathrm{R}$ & $\mathrm{LC}$ \\
\hline Charadriidae & African Wattled Plover & Vanellus senegallus & $\mathrm{R}$ & $\mathrm{LC}$ \\
\hline Charadriidae & Spur-winged Plover & Vanellus spinosus & $\mathrm{R}$ & LC \\
\hline Ciconiidae & Marabou Stork & Leptoptilos crumeniferus & $\mathrm{R}$ & $\mathrm{LC}$ \\
\hline Sylviidae & Green-backed Eremomela & Eremomela canescens & $\mathrm{R}$ & LC \\
\hline Cisticolidae & Grey-backed Camaroptera & Camaroptera brachyura & $\mathrm{R}$ & LC \\
\hline Cisticolidae & Red-faced Cisticola & Cisticola erythrops & $\mathrm{R}$ & LC \\
\hline
\end{tabular}




\section{Continued}

\begin{tabular}{|c|c|c|c|c|}
\hline Cisticolidae & Tawny-flanked Prinia & Prinia subflava & $\mathrm{R}$ & LC \\
\hline Cisticolidae & Winding Cisticola & Cisticola galactotes & $\mathrm{R}$ & LC \\
\hline Coliidae & Blue-naped Mousebird & Urocolius macrourus & $\mathrm{R}$ & LC \\
\hline Coliidae & Speckled Mousebird & Colius striatus & $\mathrm{R}$ & LC \\
\hline Columbidae & African Green Pigeon & Treron calvus & $\mathrm{R}$ & LC \\
\hline Columbidae & Blue-spotted Wood Dove & Turtur afer & $\mathrm{R}$ & LC \\
\hline Columbidae & Red-eyed Dove & Streptopelia semitorquata & $\mathrm{R}$ & LC \\
\hline Columbidae & Ring-necked Dove & Streptopelia capicola & $\mathrm{R}$ & LC \\
\hline Columbidae & Speckled Pigeon & Columba guinea & $\mathrm{R}$ & LC \\
\hline Coraciidae & Lilac-breasted Roller & Coracias caudatus & $\mathrm{am}$ & LC \\
\hline Corvidae & Pied Crow & Corvus albus & $\mathrm{R}$ & LC \\
\hline Malaconotidae & Black-crowned Tchagra & Tchagra senegalus & $\mathrm{R}$ & LC \\
\hline Cuculidae & Common Cuckoo & Cuculus canorus & $\mathrm{PM}$ & LC \\
\hline Cuculidae & Jacobin Cuckoo & Clamator jacobinus & $\mathrm{am}, \mathrm{pm}$ & LC \\
\hline Cuculidae & Klaas's Cuckoo & Chrysococcyx klaas & $\mathrm{R}$ & LC \\
\hline Cuculidae & White-browed Coucal & Centropus superciliosus & $\mathrm{R}$ & LC \\
\hline Dicruridae & Common Drongo & Dicrurus adsimilis & $\mathrm{R}$ & LC \\
\hline Estrildidae & African Firefinch & Lagonosticta rubricata & $\mathrm{R}$ & LC \\
\hline Estrildidae & Red-billed Firefinch & Lagonosticta senegala & $\mathrm{R}$ & LC \\
\hline Estrildidae & Red-cheeked Cordon-bleu & Uraeginthus bengalus & $\mathrm{R}$ & LC \\
\hline Fringillidae & Oriole Finch & Linurgus olivaceus & $\mathrm{R}$ & $\mathrm{LC}$ \\
\hline Fringillidae & Yellow-fronted Canary & Crithagra mozambica & $\mathrm{R}$ & LC \\
\hline Hirundinidae & Black Saw-wing & Psalidoprocne pristoptera & $\mathrm{R}$ & LC \\
\hline Hirundinidae & Lesser Striped Swallow & Cecropis abyssinica & $\mathrm{R}$ & LC \\
\hline Hirundinidae & Mosque Swallow & Cecropis senegalensis & $\mathrm{R}$ & LC \\
\hline Hirundinidae & Red-rumped Swallow & Cecropis daurica & $\mathrm{R}$ & LC \\
\hline Hirundinidae & Wire-tailed Swallow & Hirundo smithii & $\mathrm{R}$ & LC \\
\hline Indicatoridae & Lesser Honeyguide & Indicator minor & $\mathrm{R}$ & LC \\
\hline Jacanidae & African Jacana & Actophilornis africanus & $\mathrm{R}$ & LC \\
\hline Laniidae & Common Fiscal & Lanius collaris & $\mathrm{R}$ & LC \\
\hline Leiothrichidae & Arrow-marked Babbler & Turdoides jardineii & $\mathrm{R}$ & LC \\
\hline Lybiidae & Yellow-fronted Tinkerbird & Pogoniulus chrysoconus & $\mathrm{R}$ & LC \\
\hline Macrosphenidae & Moustached Grass Warbler & Melocichla mentalis & $\mathrm{R}$ & LC \\
\hline Malaconotidae & Black-headed Gonolek & Laniarius erythrogaster & $\mathrm{R}$ & LC \\
\hline Malaconotidae & Tropical Boubou & Laniarius aethopicus & $\mathrm{R}$ & LC \\
\hline Nectariniidae & Bronze Sunbird & Nectarinia kilimensis & $\mathrm{R}$ & LC \\
\hline Meropidae & Eurasian Bee-eater & Merops apiaster & $\mathrm{pm}$ & LC \\
\hline
\end{tabular}




\section{Continued}

\begin{tabular}{|c|c|c|c|c|}
\hline Apodidae & Little Swift & Apus affinis & $\mathrm{R}$ & LC \\
\hline Meropidae & White-throated Bee-eater & Merops albicollis & am & LC \\
\hline Motacillidae & Tree Pipit & Anthus trivialis & $\mathrm{pm}$ & LC \\
\hline Motacillidae & Yellow Wagtail & Motacilla flava & $\mathrm{pm}$ & LC \\
\hline Motacillidae & Yellow-throated Longclaw & Macronyx croceus & $\mathrm{R}$ & LC \\
\hline Monarchidae & African Blue Flycatcher & Elminia longicauda & $\mathrm{R}$ & LC \\
\hline Muscicapidae & African Paradise Flycatcher & Terpsiphone viridis & am & LC \\
\hline Muscicapidae & Northern Black Flycatcher & Melaenornis edolioides & $\mathrm{R}$ & LC \\
\hline Muscicapidae & Spotted Flycatcher & Muscicapa striata & $\mathrm{pm}$ & LC \\
\hline Muscicapidae & Swamp Flycatcher & Muscicapa aquatica & $\mathrm{R}$ & LC \\
\hline Muscicapidae & White-browed Scrub Robin & Cercotrichas leucophrys & $\mathrm{R}$ & LC \\
\hline Musophagidae & Eastern Grey Plantain-eater & Crinifer zonurus & $\mathrm{R}$ & LC \\
\hline Gruidae & Grey Crowned Crane & Balearica regulorum & $\mathrm{R}$ & $\mathrm{V}$ \\
\hline Musophagidae & Ross's Turaco & Musophaga rossae & $\mathrm{R}$ & LC \\
\hline Nectariniidae & Green-headed Sunbird & Cyanomitra verticalis & $\mathrm{R}$ & LC \\
\hline Nectariniidae & Purple-banded Sunbird & Cinnyris bifasciatus & $\mathrm{R}$ & LC \\
\hline Nectariniidae & Scarlet-chested Sunbird & Chalcomitra senegalensis & $\mathrm{R}$ & LC \\
\hline Nectariniidae & Variable Sunbird & Cinnyris venustus & $\mathrm{R}$ & LC \\
\hline Numididae & Helmeted Guineafowl & Numida meleagris & $\mathrm{R}$ & LC \\
\hline Hirundinidae & Barn Swallow & Hirundo rustica & $\mathrm{pm}$ & LC \\
\hline Oriolidae & Black-headed Oriole & Oriolus larvatus & $\mathrm{R}$ & LC \\
\hline Accipitridae & Great Sparrowhawk & Accipiter melanoleucus & $\mathrm{R}$ & LC \\
\hline Passeridae & Grey-headed Sparrow & Passer griseus & $\mathrm{R}$ & LC \\
\hline Passeridae & House Sparrow & Passer domesticus & $\mathrm{R}$ & LC \\
\hline Picidae & Cardinal Woodpecker & Dendropicos fuscescens & $\mathrm{R}$ & LC \\
\hline Picidae & Nubian Woodpecker & Campethera nubica & $\mathrm{R}$ & LC \\
\hline Picidae & Red-throated Wryneck & Jynx ruficollis & $\mathrm{R}$ & LC \\
\hline Platysteiridae & Black-headed Batis & Batis minor & $\mathrm{R}$ & LC \\
\hline Platysteiridae & Brown-throated Wattle-eye & Platysteira cyanea & $\mathrm{R}$ & LC \\
\hline Ploceidae & Compact Weaver & Ploceus superciliosus & $\mathrm{R}$ & LC \\
\hline Ploceidae & Fan-tailed Widowbird & Euplectes axillaris & $\mathrm{R}$ & LC \\
\hline Ploceidae & Holub's Golden Weaver & Ploceus xanthops & $\mathrm{R}$ & LC \\
\hline Ploceidae & Red-headed Weaver & Anaplectes melanotis & $\mathrm{R}$ & LC \\
\hline Ploceidae & Spectacled Weaver & Ploceus ocularis & $\mathrm{R}$ & LC \\
\hline Ploceidae & Village Weaver & Ploceus cucullatus & $\mathrm{R}$ & LC \\
\hline Ploceidae & Yellow-backed Weaver & Ploceus melanocephalus & $\mathrm{R}$ & LC \\
\hline Psittacidae & Fischer's Lovebird & Agapornis fischeri & $\mathrm{R}$ & NT \\
\hline
\end{tabular}




\section{Continued}

\begin{tabular}{ccccc}
\hline Psittacidae & Meyer's Parrot & Poicephalus meyeri & $\mathrm{R}$ & $\mathrm{LC}$ \\
Pycnonotidae & Common Bulbul & Pycnonotus barbatus & $\mathrm{R}$ & $\mathrm{LC}$ \\
Pycnonotidae & Yellow-throated Leaflove & Chlorocichla flavicollis & $\mathrm{R}$ & $\mathrm{LC}$ \\
Scolopacidae & Common Sandpiper & Actitis hypoleucos & $\mathrm{pm}$ & $\mathrm{LC}$ \\
Scolopacidae & Green Sandpiper & Tringa ochropus & $\mathrm{pm}$ & $\mathrm{LC}$ \\
Sturnidae & Greater Blue-eared Starling & Lamprotornis chalybaeus & $\mathrm{R}$ & $\mathrm{LC}$ \\
Sturnidae & Red-billed Oxpecker & Buphagus erythrorhynchus & $\mathrm{R}$ & $\mathrm{LC}$ \\
Sturnidae & Rüppell's Starling & Lamprotornispurpuroptera & $\mathrm{R}$ & $\mathrm{LC}$ \\
Sturnidae & Superb Starling & Lamprotornis superbus & $\mathrm{R}$ & $\mathrm{LC}$ \\
Threskiornithidae & Hadada Ibis & Bostrychia hagedash & $\mathrm{R}$ & $\mathrm{LC}$ \\
Threskiornithidae & Sacred Ibis & Threskiornis aethiopicus & $\mathrm{R}$ & $\mathrm{LC}$ \\
Timaliidae & Black-lored Babbler & Turdoides sharpei & $\mathrm{R}$ & $\mathrm{LC}$ \\
Muscicapidae & Whinchat & Saxicola rubetra & $\mathrm{pm}$ & $\mathrm{LC}$ \\
Muscicapidae & White-browed Robin Chat & Cossypha heuglini & $\mathrm{R}$ & $\mathrm{LC}$ \\
Viduidae & Pin-tailed Whydah & Vidua macroura & $\mathrm{R}$ & $\mathrm{LC}$ \\
\hline
\end{tabular}

Legend: NT: Near threatened; V: Vulnerable; LC: Least concern; am: Afrotropical migrant; pm: Palearctic migrant; R: Resident.

\section{Appendix 2. Nyando Sugar Belt Bird Species Showing Forest Category (See Legend for Initials Used)}

\begin{tabular}{ccc}
\hline Common Name & Scientific Name & Forest Dependency \\
\hline African Black-shouldered Kite & Elanus caeruleus & Non $\mathrm{f}$ \\
African Blue Flycatcher & Elminia longicauda & $\mathrm{F}$ \\
African Firefinch & Lagonosticta rubricata & Non $\mathrm{f}$ \\
African Green Pigeon & Treron calvus & $\mathrm{F}$ \\
African Harrier Hawk & Polyboroides typus & $\mathrm{F}$ \\
African Jacana & Actophilornis africanus & Non $\mathrm{f}$ \\
African Palm Swift & Cypsiurus parvus & Non f \\
African Paradise Flycatcher & Terpsiphone viridis & $\mathrm{F}$ \\
African Pied Wagtail & Motacilla aguimp & Non $\mathrm{f}$ \\
African Thrush & Turdus pelios & $\mathrm{F}$ \\
African Wattled Plover & Vanellus senegallus & Non f \\
Arrow-marked Babbler & Turdoides jardineii & Non f \\
Barn Swallow & Hirundo rustica & Non f \\
Black Cuckooshrike & Campephaga flava & $\mathrm{f}$ \\
Black Kite & Milvus migrans & Non f \\
Black Saw-wing & Psalidoprocne pristoptera & $\mathrm{f}$ \\
Black-crowned Tchagra & Tchagra senegalus & Non $\mathrm{f}$ \\
Black-headed Batis & Batis minor & \\
\hline & & \\
\hline
\end{tabular}




\section{Continued}

\begin{tabular}{|c|c|c|}
\hline Black-headed Gonolek & Laniarius erythrogaster & Non $f$ \\
\hline Black-headed Heron & Ardea melanocephala & Non $f$ \\
\hline Black-headed Oriole & Oriolus larvatus & $\mathrm{f}$ \\
\hline Black-lored Babbler & Turdoides sharpei & Non $f$ \\
\hline Blue-naped Mousebird & Urocolius macrourus & Non $f$ \\
\hline Blue-spotted Wood Dove & Turtur afer & $\mathrm{f}$ \\
\hline Bronze Mannikin & Spermestes cucculatus & Non $f$ \\
\hline Bronze Sunbird & Nectarinia kilimensis & $\mathrm{f}$ \\
\hline Brown-throated Wattle-eye & Platysteira cyanea & $\mathrm{f}$ \\
\hline Cardinal Woodpecker & Dendropicos fuscescens & $\mathrm{f}$ \\
\hline Cattle Egret & Bubulcus ibis & Non $f$ \\
\hline Common Bulbul & Pycnonotus barbatus & $\mathrm{f}$ \\
\hline Common Buzzard & Buteo buteo & Non $f$ \\
\hline Common Cuckoo & Cuculus canorus & Non $f$ \\
\hline Common Drongo & Dicrurus adsimilis & Non $f$ \\
\hline Common Fiscal & Lanius collaris & Non $f$ \\
\hline Common Sandpiper & Actitis hypoleucos & Non $f$ \\
\hline Compact Weaver & Ploceus superciliosus & $\mathrm{f}$ \\
\hline Double-toothed Barbet & Lybius bidentatus & $\mathrm{f}$ \\
\hline Eastern Grey Plantain-eater & Crinifer zonurus & Non $f$ \\
\hline Eurasian Bee-eater & Merops apiaster & $\mathrm{f}$ \\
\hline Fan-tailed Widowbird & Euplectes axillaris & Non $f$ \\
\hline Fawn-coloured Lark & Mirafra africanoides & Non $f$ \\
\hline Fischer's Lovebird & Agapornis fischeri & Non $f$ \\
\hline Flappet Lark & Mirafra rufocinnamomea & Non $f$ \\
\hline Great Sparrowhawk & Accipiter melanoleucus & $\mathrm{F}$ \\
\hline Greater Blue-eared Starling & Lamprotornis chalybaeus & Non $f$ \\
\hline Green Sandpiper & Tringa ochropus & Non $f$ \\
\hline Green-backed Eremomela & Eremomela canescens & Non $f$ \\
\hline Green-headed Sunbird & Cyanomitra verticalis & $\mathrm{f}$ \\
\hline Grey Crowned Crane & Balearica regulorum & Non $\mathrm{f}$ \\
\hline Grey Heron & Ardea cinerea & Non $f$ \\
\hline Grey-backed Camaroptera & Camaroptera brachyura & $\mathrm{f}$ \\
\hline Grey-headed Sparrow & Passer griseus & Non $f$ \\
\hline Hadada Ibis & Bostrychia hagedash & Non $f$ \\
\hline Helmeted Guineafowl & Numida meleagris & Non $f$ \\
\hline Holub's Golden Weaver & Ploceus xanthops & Non $\mathrm{f}$ \\
\hline
\end{tabular}




\section{Continued}

\begin{tabular}{|c|c|c|}
\hline House Sparrow & Passer domesticus & Non $f$ \\
\hline Jacobin Cuckoo & Clamator jacobinus & Non $f$ \\
\hline Klaas's Cuckoo & Chrysococcyx klaas & $\mathrm{f}$ \\
\hline Lesser Honeyguide & Indicator minor & $\mathrm{f}$ \\
\hline Lesser Striped Swallow & Cecropis abyssinica & Non $f$ \\
\hline Lilac-breasted Roller & Coracias caudatus & $\mathrm{f}$ \\
\hline Little Egret & Egretta garzetta & $\operatorname{non} \mathrm{f}$ \\
\hline Little Swift & Apus affinis & Non $f$ \\
\hline Malachite Kingfisher & Alcedo cristata & Non $\mathrm{f}$ \\
\hline Marabou Stork & Leptoptilos crumeniferus & Non $f$ \\
\hline Meyer's Parrot & Poicephalus meyeri & Non $f$ \\
\hline Mosque Swallow & Cecropis senegalensis & Non $f$ \\
\hline Moustached Grass Warbler & Melocichla mentalis & Non $f$ \\
\hline Northern Black Flycatcher & Melaenornis edolioides & Non $f$ \\
\hline Nubian Woodpecker & Campethera nubica & Non $f$ \\
\hline Oriole Finch & Linurgus olivaceus & $\mathrm{F}$ \\
\hline Palm-nut Vulture & Gypohierax angolensis & Non $f$ \\
\hline Pied Crow & Corvus albus & Non $\mathrm{f}$ \\
\hline Pin-tailed Whydah & Vidua macroura & Non $f$ \\
\hline Purple-banded Sunbird & Cinnyris bifasciatus & $\mathrm{f}$ \\
\hline Red-billed Firefinch & Lagonosticta senegala & Non $f$ \\
\hline Red-billed Oxpecker & Buphagus erythrorhynchus & Non $f$ \\
\hline Red-cheeked Cordon-bleu & Uraeginthus bengalus & Non $f$ \\
\hline Red-eyed Dove & Streptopelia semitorquata & $\mathrm{f}$ \\
\hline Red-faced Cisticola & Cisticola erythrops & Non $f$ \\
\hline Red-headed Weaver & Anaplectes melanotis & $\mathrm{f}$ \\
\hline Red-rumped Swallow & Cecropis daurica & Non $f$ \\
\hline Red-throated Wryneck & Jynx ruficollis & $\mathrm{f}$ \\
\hline Ring-necked Dove & Streptopelia capicola & $\mathrm{f}$ \\
\hline Ross's Turaco & Musophaga rossae & $\mathrm{F}$ \\
\hline Rüppell's Starling & Lamprotornis purpuroptera & $\mathrm{F}$ \\
\hline Sacred Ibis & Threskiornis aethiopicus & Non $f$ \\
\hline Scarlet-chested Sunbird & Chalcomitra senegalensis & Non $f$ \\
\hline Speckled Mousebird & Colius striatus & Non $f$ \\
\hline Speckled Pigeon & Columba guinea & Non $f$ \\
\hline Spectacled Weaver & Ploceus ocularis & Non $f$ \\
\hline Spot-flanked Barbet & Tricholaema lacrymosa & Non $\mathrm{f}$ \\
\hline
\end{tabular}




\section{Continued}

\begin{tabular}{|c|c|c|}
\hline Spotted Flycatcher & Muscicapa striata & Non $\mathrm{f}$ \\
\hline Spur-winged Plover & Vanellus spinosus & Non $f$ \\
\hline Steppe Eagle & Aquila nepalensis & Non $f$ \\
\hline Striated Heron & Butorides striata & Non $\mathrm{f}$ \\
\hline Superb Starling & Lamprotornis superbus & Non $f$ \\
\hline Swamp Flycatcher & Muscicapa aquatica & $\mathrm{f}$ \\
\hline Tawny-flanked Prinia & Prinia subflava & $\mathrm{f}$ \\
\hline Tree Pipit & Anthus trivialis & $\mathrm{f}$ \\
\hline Tropical Boubou & Laniarius aethopicus & $\mathrm{f}$ \\
\hline Variable Sunbird & Cinnyris venustus & $\mathrm{f}$ \\
\hline Village Weaver & Ploceus cucullatus & Non $f$ \\
\hline Wahlberg's Eagle & Aquila wahlbergi & Non $f$ \\
\hline Western Banded Snake Eagle & Circaetus cinerascens & $\mathrm{F}$ \\
\hline Western Marsh Harrier & Circus aeruginosus & Non $f$ \\
\hline Whinchat & Saxicola rubetra & $\mathrm{f}$ \\
\hline White-browed Coucal & Centropus superciliosus & Non $\mathrm{f}$ \\
\hline White-browed Robin Chat & Cossypha heuglini & $\mathrm{f}$ \\
\hline White-browed Scrub Robin & Cercotrichas leucophrys & Non $f$ \\
\hline White-faced Whistling Duck & Dendrocygna viduata & Non $f$ \\
\hline White-throated Bee-eater & Merops albicollis & Non $f$ \\
\hline Winding Cisticola & Cisticola galactotes & Non $f$ \\
\hline Wire-tailed Swallow & Hirundo smithii & Non $\mathrm{f}$ \\
\hline Woodland Kingfisher & Halcyon senegalensis & Non $f$ \\
\hline Yellow Wagtail & Motacilla flava & Non $f$ \\
\hline Yellow-backed Weaver & Ploceus melanocephalus & Non $f$ \\
\hline Yellow-fronted Canary & Crithagra mozambica & $\mathrm{f}$ \\
\hline Yellow-fronted Tinkerbird & Pogoniulus chrysoconus & Non $f$ \\
\hline Yellow-throated Leaflove & Chlorocichla flavicollis & $\mathrm{f}$ \\
\hline Yellow-throated Longclaw & Macronyx croceus & Non $f$ \\
\hline
\end{tabular}

Legend: FF: Forest Specialist; F: Forest generalist; f: Forest visitor; Non f: Non forest bird. 